\title{
The Scribble family in cancer: twentieth anniversary
}

\author{
Marie-Josée Santoni $\mathbb{D}^{1} \cdot$ Rudra Kashyap ${ }^{1,2} \cdot$ Luc Camoin $\mathbb{D}^{3} \cdot$ Jean-Paul Borg $\mathbb{( D}^{1,3,4}$
}

Received: 25 May 2020 / Revised: 5 August 2020 / Accepted: 15 September 2020 / Published online: 30 September 2020

(c) The Author(s), under exclusive licence to Springer Nature Limited 2020

\begin{abstract}
Among the more than $160 \mathrm{PDZ}$ containing proteins described in humans, the cytoplasmic scaffold Scribble stands out because of its essential role in many steps of cancer development and dissemination. Its fame has somehow blurred the importance of homologous proteins, Erbin and Lano, all belonging to the LRR and PDZ (LAP) protein family first described twenty years ago. In this review, we will retrace the history of LAP family protein research and draw attention to their contribution in cancer by detailing the features of its members at the structural and functional levels, and highlighting their shared-but also different-implication in the tumoral process.
\end{abstract}

\section{Introduction}

Cytoplasmic scaffold proteins shape the organization of macromolecular complexes involved in multiple cellular functions including cell proliferation, differentiation, signaling, death, tissue formation and homeostasis. As an example, organism models as 'simple' as yeast Saccharomyces cerevisiae rely on the Ste5 scaffold protein to assemble into a functional MAPK signaling complex containing the Ste11, Ste7, and Fus3 protein kinases which is important for mating [1]. The human genome encodes a

These authors contributed equally: Marie-Josée Santoni and Rudra Kashyap

Supplementary information The online version of this article (https:// doi.org/10.1038/s41388-020-01478-7) contains supplementary material, which is available to authorised users.

Marie-Josée Santoni

marie-josee.santoni@inserm.fr

$\triangle$ Jean-Paul Borg

jean-paul.borg@inserm.fr

1 Centre de Recherche en Cancérologie de Marseille, CRCM, Equipe labellisée Ligue 'Cell Polarity, Cell Signaling and Cancer', Aix Marseille Université, Inserm, CNRS, Institut Paoli-Calmettes, 13009 Marseille, France

2 Cellular and Molecular Medicine, Katholisch University of Leuven, Leuven, Belgium

3 Aix Marseille Université, CNRS, Inserm, Institut Paoli-Calmettes, CRCM, Marseille Protéomique, Marseille, France

4 Institut Universitaire de France (IUF), Paris, France repertoire of hundreds scaffold proteins classified according to their composition into protein-protein or protein-lipid interactions, a few of them bearing enzymatic domains. Their mosaic composition allows each scaffold protein to interact with itself or with other proteins at the plasma membrane or inside the cell, and to act as building blocks for macromolecular assemblies which localize in specific subcellular compartments and coordinate cell functions.

The Scribble PDZ scaffold protein was first identified in 2000 in Drosophila melanogaster [2] and subsequently in humans [3-5]. Based on a genetic screen aimed at revealing new factors involved in epithelial cell polarity, Bilder and Perrimon cloned the Drosophila scribble gene encoding a protein with sixteen amino-terminal LRR and four carboxyterminal PDZ domains. Loss of function of scribble results in a striking mislocalization of apical proteins and adherens junctions in polarized structures, and disruption of the monolayer organization of embryonic epithelia. The same year, our lab and the team of Michel Labouesse published two papers back-to-back revealing the existence of epithelial Scribble homologs named Erbin (ERBB2 Interacting Protein, ERBB2IP) and Let-413 in humans and Caenorhabditis elegans, respectively [6, 7]. These homologs have sixteen LRRs but only one PDZ domain, much like Densin-180/LRRC7 previously characterized in neurons [8]. A collective nomenclature for this group of novel PDZ proteins was soon proposed in reference to the presence of LRR and PDZ domains (LAP protein family, from the initials of the protein domain names) [9]. Two years later, we extracted from Metazoan genomes additional lap gene sequences and proposed a phylogenetic interpretation of their diversity [10] (Fig. 1). 
Fig. 1 The LAP family is conserved in evolution. The modules which composed the LAP are: Leucine Rich Repeat (LRR), LAP Specific Domains (LAPSD) and PSD-95/Dlg/ZO-1 (PDZ), and PDZ Binding Motives (PDZ-BMs). Conserved cysteine residues are represented by two red triangles and dual S-Palmitoyl groups as green zigzags. The gray scale bar corresponds to 100 amino-acid residues.
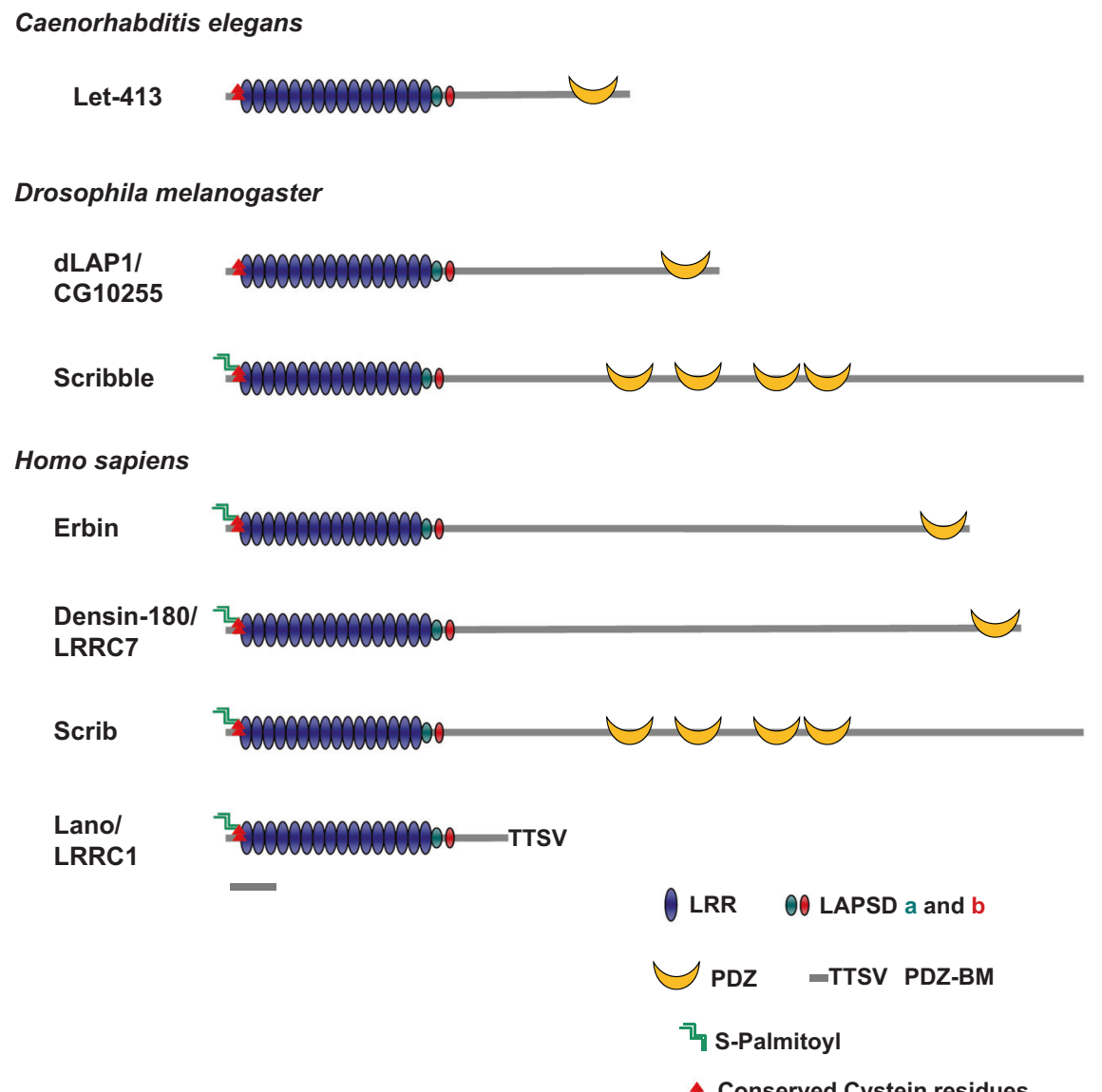

Whereas Let-413 and Scribble were identified through genetic screens for loss-of-function alleles altering invertebrate epithelial morphogenesis, Erbin was characterized as a binding partner of the PDZ binding motif (PDZBM) found in ERBB2/HER2, a tyrosine kinase receptor with crucial roles in development and oncogenesis [11]. Human Erbin is a large $180 \mathrm{kDa}$ protein which, like its homolog Let-413, localizes at the basolateral membrane of polarized epithelial cells, as well as at post-synaptic densities where it binds to cell surface receptors $[6,12]$. In addition to mammalian Scribble, Erbin, and Densin-180, we identified a fourth LAP family member, Lano/LRRC1 (hereafter named Lano) which, despite the lack of PDZ domain, is a paralogue of Scribble and similarly localizes at the basolateral side of epithelial cells [13] (Fig. 1).

Scribble is, by far, the most studied LAP protein over the past two decades. The literature describes its essential role in embryonic development in vertebrates, its role in apicobasal and planar cell polarities (PCP) and its important contribution to cancer development $[14,15]$. Role for Erbin and Lano has also been reported in cancer. We will now detail the shared features as well as the differences of these LAP proteins at the structural, functional, and physiopathological levels.

\section{Structural organization of LAP family members}

To fully understand the normal and pathological functions of scaffolds such as LAP proteins, it is necessary to dissect the role of each protein interaction domain (LRR, LAPSD, and PDZ) that build these proteins.

\section{Leucine rich repeats}

LRRs are structural motives of 20-30 amino acids which fold into $\alpha / \beta$ horseshoe-like ternary structures [16] (Fig. 2a). The role of the LRR domains of Scribble, Erbin, and their invertebrate homologs was investigated through structurefunction studies in cellulo and in vivo [5, 17-19]. These experiments originally showed that the LRRs are both necessary and sufficient to localize LAP proteins to the plasma membrane, and mandatory for LAP functions $[5,17]$. However, other recent studies stated that the covalent and reversible $\mathrm{N}$-terminal palmitoylation of LAP proteins is responsible for their membrane localization. Indeed, the N-terminal terminus of LAP family members contains two conserved S-palmitoylable cysteine residues which were shown to be post-translationally modified [20-22] 
Fig. 2 Structure of LAP domains. a The Erbin LRR domains were modeled with the Phyre2 software using the PDB4u08 LRR protein (35\% identity with Erbin LRRs) as a template. The $\alpha$-helices and the $\beta$-sheets are shown in orange and blue, respectively. $\mathbf{b}$ The Scribble PDZ1 domain bound to a $\beta$-PIX C-term peptide (turquoise blue) (PDB Scrib: 5VWK) [29] and the Erbin PDZ domain (c) bound to ERBB2 Cterminal peptide (PDB: 1MFG) [30] are represented using the Phyre2 software [127].
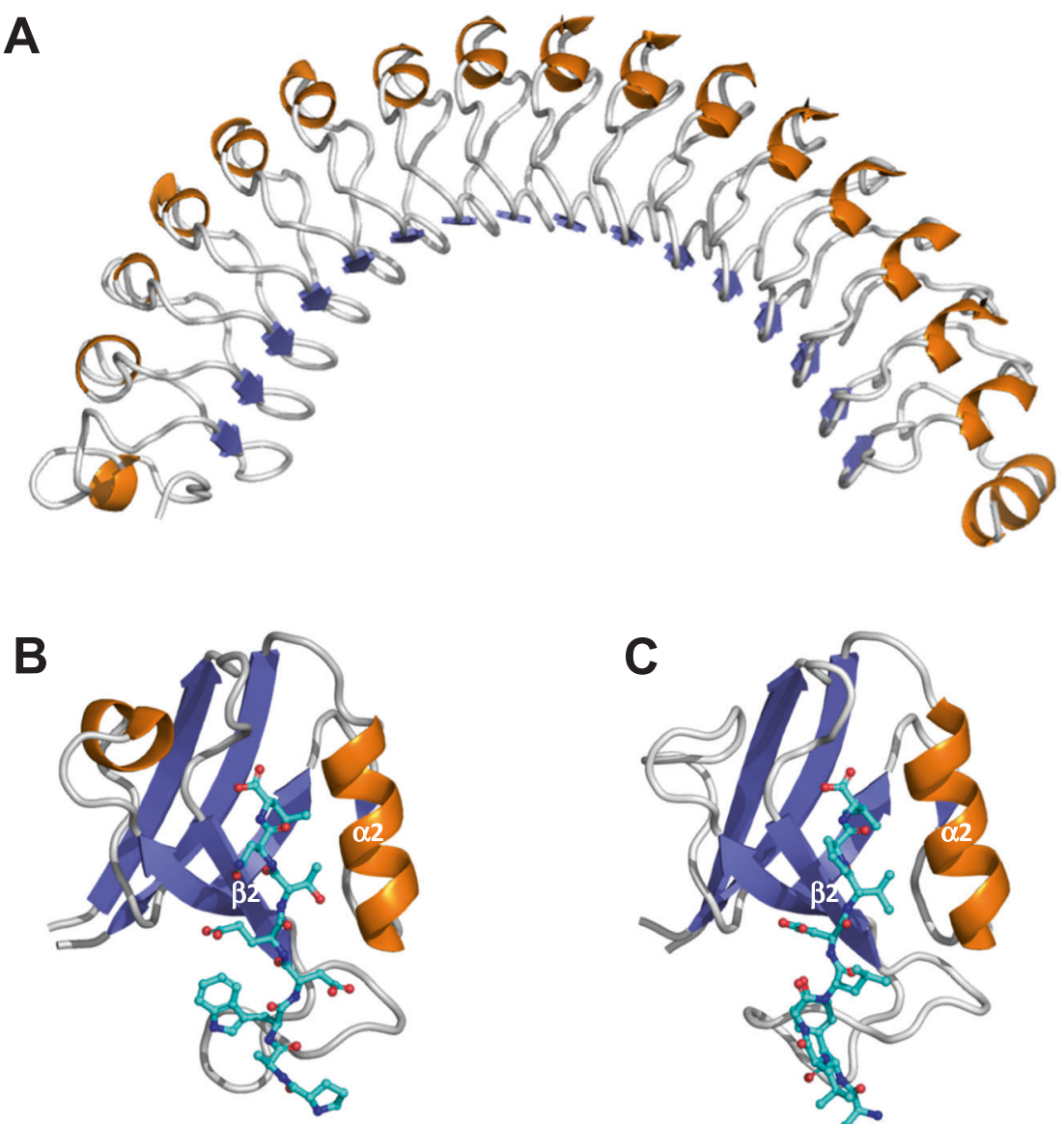

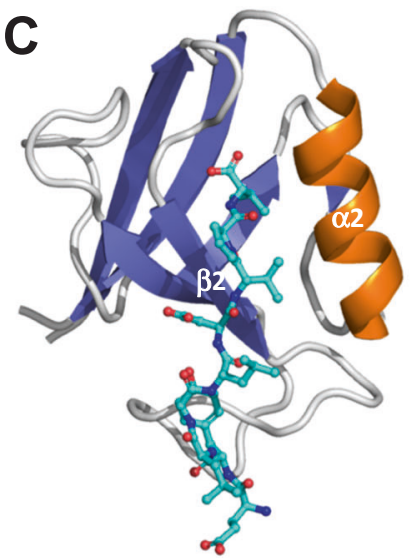

(Fig. 1). According to SwissPalm (https://swisspalm.org/), a database that compiles several palmitoyl-proteome studies, Lano is palmitoylated as is the case for other LAPs. Dynamic membrane anchoring of LAP proteins is regulated by palmitoylation/depalmitoylation cycles which were best documented for Scribble. Indeed, ZDHHC7 (Zinc finger DHHC-type palmitoyl Acyltransferase 7) and APT2 (Acyl Protein Thioesterase 2) were identified as enzymes involved in the reversible palmitoylation of Scribble [20, 23]. Interestingly, ZDHHC7-mediated palmitoylation is critical for membrane targeting, cell polarity and tumor suppression in a LRR-dependent manner [20]. Although this has not been proven experimentally yet, it is likely that Erbin and Lano are substrates of the same group of enzymes, as this sequence is conserved at their $\mathrm{N}$-terminus. However, the role of palmitoylation in membrane anchoring of LAP proteins has been questioned in some studies [21, 24].

\section{LAPSDs}

The LAP LRRs are followed by two LAP specific domains (LAPSDa and $b$ ) which are the signature of the LAP family proteins [10] (Fig. 1). LAPSDa consists in a 38-amino acid
LRR-like domain adjacent to a second 24-residue conserved region (LAPSDb) unrelated to LRR motifs. It was only recently shown that LAPSDb is essential for basolateral localization of LAP proteins and LAPSDa for basolateral identity and interaction with the Lgl tumor suppressor [25] (Fig. 1).

\section{PDZ domains}

PDZ domains were originally classified into three classes according to their binding specificity towards carboxyterminal PDZ binging motives (PDZBM) [26]. However, ligand selectivity of PDZ domains is far more complex [27]. The Scribble, Erbin, and Densin-180 PDZ domains display a class I binding specificity with affinity to X-T/S-X $\Phi$ PDZBMs (where $\mathrm{T}$ is threonine, $\mathrm{S}$ is serine, $\mathrm{X}$ is any amino acid, and $\Phi$ is a hydrophobic residue). However, the Erbin PDZ domain has a dual ligand specificity and also binds to class II X- $\Phi-\mathrm{X}-\Phi$ PDZBMs [28]. The PDZ domains of Scribble follow the PDZ class I canonical structure (Fig. 2b) [29]. In contrast, Erbin contains an atypical class I PDZ domain that lacks the short $\alpha$-helix (called $\alpha 1$ in other PDZs such as those of Scribble) present between the $\beta 3$ and 
$\beta 4$ strands (Fig. 2c) and seems to have an intrinsic flexibility that enables it to bind to class I or II PDZBMs such as those found in p0071/delta-catenin and ERBB2, respectively $[6,30,31]$. Structural analysis has allowed to unravel the molecular basis of class II ligand recognition by the class I Erbin PDZ. The side chain of valine at position -2 of the ERBB2 PDZBM $\left(-\mathrm{V}^{-2} \mathrm{PV}\right)$ interacts with valine ${ }^{1351}$ of Erbin and displaces the peptide backbone away from the helix $\alpha$ [30]. In addition, Erbin presents an unusually long loop between $\beta 2$ and $\beta 3$ strands ( $\beta 2: \beta 3$ loop) compared to canonical PDZ domains $[30,32]$ (Fig. 2c). Cocrystallization analysis shows that this $\beta 2: \beta 3$ loop is able to interact with tyrosine ${ }^{1248}$ at position -7 of the ERBB2 PDZBM which plays a crucial role in ERBB2 signaling. The PDZ domain of Erbin binds to the native ERBB2 peptide with good affinity but not with the phosphorylated version on tyrosine 1248, suggesting the regulation of the Erbin-ERBB2 interaction by the active state of the receptor $[6,30]$.

Finally, whereas Lano lacks a PDZ domain, it carries a bona fide carboxy-terminal PDZBM (-TTSV) (Fig. 1) which recognizes class I PDZ domains such as those found in PSD-95. Interestingly, Lano interacts with Erbin indirectly through PSD-95, and with Scribble most probably through a PDZ domain interaction [13, 33].

\section{Protein networks associated with LAP proteins}

The role of scaffold proteins is to organize macromolecular complexes into functional units at proper sites in cells. Before describing the functions of LAP proteins, we will give an overview of what is known about the interactions involving LAP proteins, from the simple (binary) interactions to the most complex interactions.

\section{LRR interactions}

At the moment, very few partners have been described for LAP LRR domains. Notably, the Ser/Thr protein kinase PHLPP1 which functions as a tumor suppressor binds to the LRR domain of Scribble through its carboxy-terminus. Knockdown of Scribble delocalizes PHLPP1 from the membrane to the cytoplasm and increases AKT phosphorylation [34]. Scribble and the cell polarity and tumor suppressor protein Lethal giant larvae 2 (Lg12) were previously shown to interact via the LRR domains of Scribble [35]. Similarly, Lano interacts in the same way with Lgl2 in vitro (unpublished data). The scaffold LRR protein SHOC2/ SUR8 was also demonstrated to bind Scribble and Erbin LRR domains forming an inhibitory complex for ERK signaling [36, 37]. It is less clear how Erbin interacts with and regulates Nod2 stimulation by a component of the bacterial wall muramyl dipeptide, leading to NF- $\mathrm{KB}$ activation and an inflammatory response. However, this interaction seems to require the LRR domains of Erbin and the Nod2 CARD domain [38].

\section{PDZ interactions}

A long list of studies have revealed numerous binding partners for Scribble and Erbin PDZ domains using various techniques, mainly yeast two hybrid screens, peptide pulldowns coupled to mass spectrometry, and peptide arrays (Table 1).

Work from several labs has shown that Scribble directly interacts through its PDZ domains with proteins playing a role in different steps of cancer development and dissemination. Direct interactions have been reported with tumor suppressors mutated in cancer, Adenomatous polyposis coli (APC), a major component of Wnt signaling [39], the lipid phosphatase PTEN [40], MCC (Mutated Colorectal Cancer) [41], and with ZO-2, a junctional protein downregulated during cancer progression [42]. The Scribble PDZ domains also tightly bind to the PDZBM of the Guanine Exchange Factor (GEF) $\beta$-PIX/ARHGEF7 which promotes cancer cell migration [43, 44]. Crystal structure and quantitative binding data revealed that Scribble PDZ1 and PDZ3 domains display the highest affinity for the $\beta$-PIX PDZBM, whereas PDZ2 displays a 20-fold weaker affinity, and PDZ4 none [29]. Scribble also forms a ternary complex with Dlg1 and SGEF, a RhoG-specific GEF, at cell-cell junctions through the PDZ1 of Scribble and an atypical internal PDZBM in SGEF [45].

Erbin was originally identified through its PDZ interaction with the carboxy-terminal sequence of ERBB2 [6] and has since then been shown to bind other PDZBMs such as those found in members of the p120 catenin family (ARVCF, p0071/PKP4/Plakophilin 4) [31, 46] and $\beta$-catenin [47] (Table 1).

DSG1/Desmoglein1, an adhesion membrane protein located in epidermal desmosomes, interacts through a cytoplasmic region with the Erbin carboxy-terminus encompassing the PDZ domain. Although mapping of this atypical interaction has not clearly demonstrated the implication of the PDZ domain, DSG1 which directs stratification and differentiation of epidermis may recruit Erbin and negatively regulate the RAS/RAF pathway triggered by EGFR/ERBB2 [48].

Scribble has a strong propensity to bind PDZBMs present in oncoviral proteins such as E6 encoded by the highrisk subgroup of human papillomaviruses (HPV-16, HPV-18) causally linked to uterine cervical carcinomas, a major cause of death in women worldwide. It is noteworthy that human Scribble (named at this time VARTUL) was first 
Table 1 Role of PDZ interactions of LAP proteins in cancer.

\begin{tabular}{|c|c|c|c|c|c|c|}
\hline $\begin{array}{l}\text { LAP } \\
\text { proteins }\end{array}$ & $\begin{array}{l}\text { PDZ } \\
\text { domains }\end{array}$ & $\begin{array}{l}\text { Interacting } \\
\text { partners }\end{array}$ & Methods & References & Role in cancer & References \\
\hline \multirow[t]{12}{*}{ Scribble } & PDZ 1, -2, -3 & $\beta$-PIX & $\begin{array}{l}\text { ITC, } \\
\text { pulldown, MS }\end{array}$ & {$[29,43]$} & $\begin{array}{l}\text { Scribble and } \beta \text {-PIX are associated with PAK. The complex } \\
\text { controls cell polarity and directed migration in cancer cells. } \\
\text { Scribble is shown to inhibit apoptosis in an } \beta \text {-PIX-Rac-JNK } \\
\text { pathway-dependent manner, and promotes proliferation in a Ras/ } \\
\text { MAPK-dependent manner in mammary and prostate epithelia. }\end{array}$ & {$[18,44,81,85]$} \\
\hline & PDZ 1, -2, -3 & APC & Pulldown, IP, ITC & {$[39,113]$} & $\begin{array}{l}\text { Scribble co-localizes with APC at the membrane protrusions. } \\
\text { Scribble siRNA disrupts localization of APC in Caco-2 cells }\end{array}$ & [113] \\
\hline & PDZ 2, -3, -4 & Vangl2 & Y2H, IP, pulldown & {$[35,114]$} & & \\
\hline & PDZ 1, -3 & MCC & Pulldown, IP, ITC & {$[41,115]$} & $\begin{array}{l}\text { MCC and Scribble colocalize at the plasma membrane of breast } \\
\text { cancer cells. Reduced expression of MCC results in impaired cell } \\
\text { migration }\end{array}$ & [41] \\
\hline & PDZ $1,-3$ & HPV16 E6 & $\begin{array}{l}\text { Phage library } \\
\text { screening, MS }\end{array}$ & {$[4,51]$} & $\begin{array}{l}\text { Proteasome mediated degradation of Scribble after HPV } \\
\text { infection, Scribble is required for HPV E6 expression in cervical } \\
\text { tumor-derived cells }\end{array}$ & {$[51,116]$} \\
\hline & PDZ 2, -3 & Tax 1 & $\begin{array}{l}\text { Pulldown, IP, } \\
\text { fluorescence } \\
\text { polarization assays }\end{array}$ & {$[28,53]$} & $\begin{array}{l}\text { Scribble interacts with Tax } 1 \text { and is essential for T-cell } \\
\text { immortalization }\end{array}$ & {$[53,54]$} \\
\hline & PDZ 3, -4 & Fat1 & Co-IP & [117] & $\begin{array}{l}\text { Scribble and Fat } 1 \text { directly interact and play a role in Hippo } \\
\text { signaling }\end{array}$ & [117] \\
\hline & PDZ 3, -4 & ZO-2 & $\begin{array}{l}\text { Pulldown, MS, } \\
\text { Co-IP }\end{array}$ & [42] & & \\
\hline & \multirow[t]{2}{*}{ PDZ 1} & RPS6KA1, A2 & $\begin{array}{l}\text { ProP-PD, MST } \\
\text { and ITC }\end{array}$ & [115] & & \\
\hline & & $\begin{array}{l}\text { TANC1, } \\
\text { TAZ, YAP1 }\end{array}$ & $\begin{array}{l}\text { ProP-PD, MST } \\
\text { and ITC }\end{array}$ & [115] & & \\
\hline & PDZ 1 & PTEN & IP & [40] & $\begin{array}{l}\text { In breast cancer, delocalization of Scribble promotes increased } \\
\text { PTEN levels and activates AKT/mTOR/S6K pathway }\end{array}$ & [40] \\
\hline & PDZ 4 & p22phox & BLI, pulldown, IP & [118] & $\begin{array}{l}\text { Scribble modulates the NOX pathway by inducing ROS } \\
\text { generation with implications for chronic inflammatory diseases, } \\
\text { sepsis, and cancer }\end{array}$ & [118] \\
\hline \multirow[t]{8}{*}{ Erbin } & PDZ & ERBB2 & $\begin{array}{l}\text { Y2H, IP, } \\
\text { ELISA, SPR }\end{array}$ & {$[6,31,62]$} & Erbin regulates ERBB2 stability in breast cancer & [88] \\
\hline & PDZ & $\beta$-catenin & $\begin{array}{l}\text { SPOT assay, } \\
\text { ELISA, CoIP }\end{array}$ & {$[47,119,120]$} & $\begin{array}{l}\text { Erbin modulates beta-catenin-dependent transcription and acts as } \\
\text { a negative regulator }\end{array}$ & {$[47,120]$} \\
\hline & PDZ & APC & Y2H, IP & [120] & $\begin{array}{l}\text { Erbin/Apc double knockout mice have increased tumor initiation } \\
\text { potential and activation of Wnt signaling is observed }\end{array}$ & {$[68]$} \\
\hline & PDZ & $\begin{array}{l}\text { p0071/ } \\
\text { Plakophilin-4 }\end{array}$ & Y2H, Co-IP, SPR & {$[62,121]$} & & \\
\hline & PDZ & Tax1 & $\begin{array}{l}\text { SPOT assay, } \mathrm{Y} 2 \mathrm{H}, \\
\text { ProP-PD }\end{array}$ & {$[28,120,122]$} & & \\
\hline & PDZ & $\mathrm{BCR}$ & SPOT assay, IP & [119] & & \\
\hline & PDZ & c-Rel & Y2H, IP & [120] & & \\
\hline & PDZ & $\begin{array}{l}\text { Delta } \\
\text { catenin, ARVCF }\end{array}$ & $\begin{array}{l}\text { ELISA, } \\
\text { pulldown, IP }\end{array}$ & [31] & & \\
\hline
\end{tabular}

ITC Isothermal Calorimetry, MS Mass Spectrometry, (co)IP (co)Immunoprecipitation, $Y 2 H$ Yeast Two Hybrid, MST Mesoscale thermophoresis, BLI Bio-Layer Interferometry, SPR Surface Plasmon Resonance, ELISA Enzyme-Linked ImmunoSorbent Assay.

identified by affinity purification followed by mass spectrometry analysis using GST-E6AP-E6 complex as a bait [4]. It has indeed been suggested that the E6-E6AP complex recruits and ubiquitinylates p53 and cell polarity proteins such as Scribble in HPV infected cells, promoting their destruction and switching off their tumor-suppressing functions [49]. Moreover, another proteomic approach demonstrated that Scribble recognition is a conserved feature in all cancer-causing HPV E6 oncoproteins and correlates directly with their increased oncogenic potential [50].

Intriguingly, in cooperation with E6, Scribble plays also a role in protein translation through the S6 kinase signaling pathway and potentially increases progression of HPVinduced malignancies [51].

Using a powerful proteomic peptide-phage display approach, Ivarsson et al. discovered previously uncharacterized viral PDZBMs binding to LAPs, among others, rabies virus glycoprotein $\mathrm{G}$ for Scribble and Bat coronavirus envelope small membrane protein for Erbin [28]. The Scribble PDZ domains were also shown to interact with other viral PDZBMs found in the NS1 protein of influenza virus [52] and in the Tax protein of Human T-cell leukemia virus type 1 (HTLV-1) [53]. A recent study attributed to the Scribble-Tax interaction a prominent role in immortalization 
of HTLV-1 infected T-cells, as found in human adult T-cell leukemia/lymphoma [54].

\section{Regions between LRRs and PDZs}

Sequences outside the LRR, LAPSD, and PDZ domains of LAP proteins are also the sites of interactions with partners, especially for Erbin. Regions in Erbin indeed interact with bullous pemphigoid antigen 1 (eBPAG1) and Integrin $\beta 4$ subunit, two components of hemidesmosomes involved in cell-substrate attachment in the skin [55], as well as with other PDZ proteins. The postsynaptic density protein-95 (PSD-95) interacts simultaneously with Erbin and with ERBB4, allowing the localization of the ERBB family members to synapses through this PDZ network [12, 13]. Erbin also interacts with the carboxy-terminus of NHERF1 (sodium/hydrogen exchanger regulatory factor1)/EBP50, which harbors two PDZ domains, thus linking Merlin/NF2 to adherens junctions [56].

An interacting motif of about 60 amino acids located close to the Erbin PDZ domain binds to SMAD2/3 and SARA (SMAD anchor for receptor activation) which are regulators of the TGF $\beta /$ Activin pathway involved in embryonic development and diseases such as cancer [57-59]. Erbin is targeted to early endosomes by SARA and, interestingly, other LAP proteins have been involved in membrane vesicle trafficking $[43,60]$. The SMAD2/3 and SARA common motif is partially shared with another partner of Erbin: MUSK (MUscle associated Receptor Tyrosine Kinase). At the neuromuscular junction, ERBB2, Erbin and MUSK negatively modulate SMAD3-mediated transcriptional activation of TGF $\beta$ target genes [61]. Finally, Erbin is able to self-associate thanks to its intermediary region and PDZ domain, and therefore enhance its efficiency of signaling [62].

\section{Large scale networks associated to LAP proteins}

The first attempt to identify endogenous interactors of Scribble was performed in our team using specific antiScribble antibodies [43]. Although the in-depth identification of protein complexes was limited at that time, our strategy led to the discovery of the $\beta$ PIX/ARGHEF7-GIT1 complex which binds to Scribble PDZ1 and PDZ3 through a PDZBM found in $\beta$ PIX. Later on, we identified the Ser/ Thr protein kinase PAK1 as another component of the complex [44]. By a single-step method or a TAP-tag purification of Scribble using epitope-tagged constructs, a more extensive network was discovered which comprises additional signaling and polarity proteins including VANGL1, VANGL2, SHOC2/SUR-8, M-RAS,... [36, 63]. We recently provided a comprehensive map of the partners of Scribble and Lano and confirmed interactions between these
LAPs and previously described binding partners ( $\beta$ PIX/ GIT, PP1, p0071 among others) [33]. Around 199 proteins are common to the Scribble and Lano networks, whereas 191 and 275 proteins including many PDZ domaincontaining proteins are specifically associated with Scribble and Lano, respectively. Interestingly, the associated network can be regulated by pharmacological inhibition of the proteasome activity.

In a recent study aiming to assess the composition of integrin-associated complexes (IACs) in pancreatic fibroblasts using proximity biotinylation [64], Scribble and Erbin were identified by mass spectrometry in these cellular structures, together with already known partners including $\beta$ PIX/GIT for Scribble and $\beta 4$-integrin for Erbin. This confirms previous studies demonstrating their presence in phosphoproteomic analysis of IACs and at the leading edge of migratory cells $[65,66]$, and their implication in cell migration [44, 67, 68].

\section{Post-translational modifications of LAP family members}

At the moment, very few studies have described the role of post-translational modifications in LAP functions besides the ones describing the reversible N-terminal dual palmitoylation of LAP proteins (see above and Fig. 1). However, multiple phosphosites in Erbin, Scribble, and Lano are found in databases with no assigned functions for most of them (Fig. 3). Three phosphorylation sites (S1378, S1508, S1601) in Scribble were shown to contribute to localization at adherens junctions and to cell contractility [69]. The lab of Lawrence Banks also showed that Scribble binds to ERK through two kinase interaction motif (KIM) docking sites, both of which are also required for ERK or PKA-induced phosphorylation of Scribble on S853 [70]. Finally, as demonstrated in the context of HPV infection, Scribble is ubiquitinylated and sensitive to proteasomal degradation triggered by E6AP [4] (Fig. 3). Of note, the intermediate filament protein Vimentin interacts with and protects Scribble from proteasomal degradation [71].

\section{Role of LAP proteins in cancer}

In Drosophila, scribble plays a major role in the control of epithelial apico-basal polarity and cell proliferation. It belongs to the same tumor-suppressing genetic pathway as discs large (dlg) and lethal giant larvae (lgl). The scribble$d \lg$ - $\lg l$ complex genetically interacts with two other sets of cell polarity genes (bazooka-apkc-par6 and stardustcrumbs-patj) in a complex manner to establish and maintain the epithelial phenotype [14, 15].

The most spectacular phenotype of mouse lap gene mutants is observed in scribble-deficient embryos which 

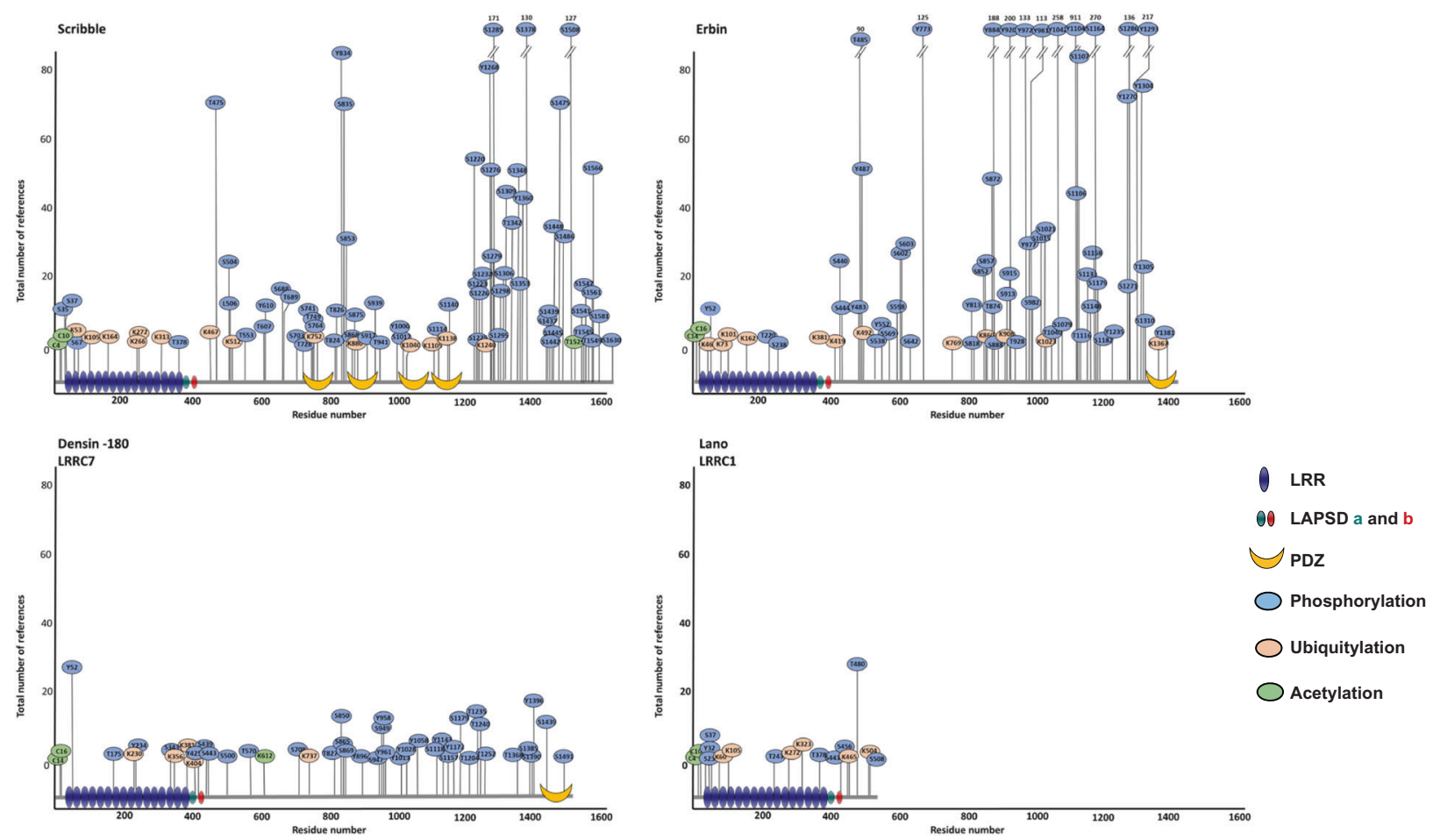

Fig. 3 Post-translational modifications in LAP family proteins. Analysis based on HTP (High Throughput Papers) and LTP (Low Throughput Papers) data available in the Phosphositeplus database. A cut-off of 5 references was set to select the phosphorylation sites.

have a completely open neural tube and abnormalities in cochlea stereocilia alignments, axonal guidance, heart formation, and lung development, all linked to PCP defects [72]. Conditional knock-out mouse models revealed other defects in synapse plasticity [73], myelinisation in the central nervous system [74], muscle regeneration [75] and mammary alveogenesis [76]. Erbin knock-out mice are viable and fertile although to a lesser extent than their wildtype counterparts, and display defects of myelinisation of the peripheral nervous system [77] and cardiac hypertrophy [78]. Densin-180/LRRC7 was identified as a candidate gene in severe childhood emotional dysregulation. This finding is consistent with the phenotype of $\operatorname{lrc} 7$ mutant mice which present juvenile aggressive and anxiety-like behaviors and social dysfunction in adulthood [79]. To our knowledge, no implication of Densin-180/LRRC7 in cancer has been reported yet. Finally, lano knock-out mice are viable and fertile with a normal Mendelian distribution [80]. However, as in scribble and erbin-deficient mice [76, 81, 82], we observed a delay in the development of the mammary epithelium in these animals (unpublished observations).

Loss of cell polarity is one of the hallmarks of cancer of epithelial origin. Considering the prominent role of Scribble in apico-basal polarity and tumor development in Drosophila, and its close conservation with its human homolog [3], it was anticipated that role of LAP proteins in cancer would be mostly due to defects of epithelial architecture and that their downregulation would contribute to human cancer aggressiveness. Mammalian Scribble was indeed reported to be important in many aspects of cancer development $[81,83,84]$. However, the reality is far more complex, as several studies have shown that Scribble and its homologs can be downregulated or overexpressed in cancer, and that they have a role in cancer beyond their function in loss of cell polarity (Table 2).

\section{Scribble}

As a review nicely detailing the role of the Scribble polarity complex in tumorigenesis was recently published [15], we will only focus here on some aspects of the role of Scribble in cancer. In many tumors, especially breast and prostate cancer, Scribble levels are low and associated with poor prognosis, supporting the notion that Scribble acts as a tumor suppressor $[5,63,85]$. Reports of interactions of Scribble with major actors of tumoral development have led to further explorations of its role in cancer in the context of this downregulation. Functional studies have indeed shown that loss of Scribble affects the subcellular localization of PTEN, activating the AKT-mTOR-S6 kinase signaling pathway and promoting mammary tumorigenesis in basal breast cancer [40]. The lab of Senthil Muthuswamy also found that the disrupted expression of Scribble in mouse mammary epithelia impairs cell polarity and apoptosis, 
Table 2 Expression of LAP proteins in cancer.

\begin{tabular}{|c|c|c|c|c|}
\hline Protein & Alteration & Tumor type & Proposed mechanisms & References \\
\hline \multirow[t]{9}{*}{ Erbin } & \multirow[t]{2}{*}{ Low exp. } & \multirow[t]{2}{*}{ Breast cancer } & Erbin regulates sensitivity to TRAIL via ErbB2/AKT/NF-kB & [91] \\
\hline & & & Absence of Erbin destabilizes ErBB2 at the membrane & [88] \\
\hline & Low exp. & Cervical cancer & Erbin induces a STAT3-dependent resistance to anoikis & [93] \\
\hline & \multirow[t]{2}{*}{ Low exp. } & \multirow[t]{2}{*}{ Colorectal cancer } & $\begin{array}{l}\text { Erbin inhibits EGFR ubiquitination and stabilizes it by } \\
\text { interacting with c-Cbl }\end{array}$ & [89] \\
\hline & & & $\begin{array}{l}\text { Erbin interacts with KSR1 and displaces it from the RAF/ } \\
\text { MEK/ERK complex }\end{array}$ & {$[68]$} \\
\hline & High exp. & Pancreatic ductal adenocarcinoma & $\begin{array}{l}\text { Causal role of Erbin accumulation in Gemcitabine chemo- } \\
\text { sensitization }\end{array}$ & [123] \\
\hline & High exp. & Hepatocellular carcinoma & Erbin destabilizes ER $\alpha$ & [124] \\
\hline & Low exp. & $\begin{array}{l}\text { Head and neck squamous cell } \\
\text { carcinomas (HNSCC) }\end{array}$ & Dsg1 requires Erbin to decrease EGFR/ERK signaling & {$[101]$} \\
\hline & Low exp. & Acute Myeloid Leukemia (AML) & $\begin{array}{l}\text { miR-183-5p negatively regulates Erbin and inhibits AML } \\
\text { progression }\end{array}$ & [96] \\
\hline \multirow[t]{9}{*}{ Scribble } & \multirow[t]{2}{*}{ High exp. } & \multirow[t]{2}{*}{ Breast cancer } & $\begin{array}{l}\text { Scribble shRNA reduces the growth of breast cancer cells in } \\
\text { xenografts }\end{array}$ & {$[63]$} \\
\hline & & & $\begin{array}{l}\text { Scribble mutant promotes an increase of PTEN level and } \\
\text { activates AKT/mTOR/S6K pathway }\end{array}$ & [40] \\
\hline & Low exp. & Breast cancer & Mislocalization MAPK/Fra1 activation & {$[5,81,82]$} \\
\hline & $\begin{array}{l}\text { Low exp. } \\
\text { misloc. }\end{array}$ & Invasive cervical cancer & $\begin{array}{l}\text { Proteasome mediated degradation of Scribble after HPV } \\
\text { infection }\end{array}$ & [116] \\
\hline & $\begin{array}{l}\text { High exp. } \\
\text { misloc. }\end{array}$ & Prostate cancer & Scribble negatively regulates the MAPK pathway & [85] \\
\hline & High exp. & Hepatocellular carcinoma & Scribble mislocalization contributes to activate AKT/ATF2 & [104] \\
\hline & $\begin{array}{l}\text { Low exp. } \\
\text { misloc. }\end{array}$ & Lung carcinoma & $\begin{array}{l}\text { Loss of Scribble and KRas hyperactivation cooperates } \\
\text { in vivo }\end{array}$ & [125] \\
\hline & Low exp. & Skin carcinogenesis & Loss of Scribble enhances skin carcinogenesis & {$[126]$} \\
\hline & Low exp. & Lymphoma & c-Myc deregulation & [87] \\
\hline \multirow[t]{2}{*}{ Lano } & Low exp. & Breast cancer & Inhibition of Wnt secretion & {$[80]$} \\
\hline & $\begin{array}{l}\text { High exp. } \\
\text { misloc. }\end{array}$ & Hepatocellular carcinoma & Hypomethylation of the gene & {$[102,103]$} \\
\hline
\end{tabular}

Low exp. low expression, High exp. High expression, Misloc. mislocalization.

ultimately leading to mammary tumorigenesis [81]. In this paper, the authors showed that Scribble cooperates with the Myc oncogene in an $\beta$ PIX/ARGHEF7- and RAC-JNKdependent manner. Stefano Piccolo's lab later found that Scribble is associated with the transcriptional coactivator TAZ at the plasma membrane of breast cancer stem cells, keeping the Hippo pathway in check. Mislocalization of Scribble due to induction of epithelial-mesenchymal transition (EMT) or Scribble depletion trigger Hippo signaling activation, thereby promoting aggressive breast cancer development [86]. Patrick Humbert's lab convincingly demonstrated a role of Scribble in murine prostate homeostasis and cancer [85]. Loss of Scribble in the prostate promotes MAPK activation, leading to hyperplasia and lowgrade tumor development. As previously shown in Drosophila [15], cooperation between Scribble loss and an oncogenic event (such as the expression of mutated K-RAS) accelerates tumor progression and the formation of invasive carcinoma. In human prostate cancers, Scribble mislocalization was found to be associated with poor survival [85]. One of the important finding of these studies is that Scribble mislocalization, sometimes associated with its overexpression as in breast cancer [40] (Table 2), is key to its tumor-suppressing activity. It is thus important to investigate the mechanism of its membrane localization. Oncogenic properties of Scribble were also described in Myc-driven B-cell lymphomagenesis [87].

\section{Erbin}

The tyrosine kinase receptor ERBB2 was the first identified Erbin binding partner. It is an orphan receptor which homodimerizes in a ligand-independent manner when overexpressed or forms heterodimers with other members of the EGFR family [11]. ERBB2-positive breast cancer patients have a poor clinical outcome and can benefit from 
specific therapies targeting the extracellular (trastuzumab, a monoclonal antibody) or the tyrosine kinase (for example lapatinib, a tyrosine kinase inhibitor) domains. The ErbinERBB2 interaction is highly specific as Erbin has no affinity for other EGFR family members, and strictly relies on the Erbin PDZ domain. In vivo evidence of the contribution of Erbin in ERBB2-mediated tumorigenesis was obtained in Erbin-deficient mice crossed with transgenic mice overexpressing ERBB2 in the mammary gland (MMTV-Neu mice) which are less prone to mammary tumor growth compared to wild type mice overexpressing ERBB2 [88]. This effect is ERBB2-specific as deficiency of Erbin has no effect in the context of tumor development triggered by polyomavirus middle $\mathrm{T}$ antigen (PyVT). Tao et al. showed that Erbin stabilizes ERBB2 by promoting the formation of a tripartite complex formed by Erbin, ERBB2, and the HSP90 chaperon. Erbin loss destabilizes this complex leading to ERBB2 proteasomal degradation [88]. A similar study showed that upregulation of Erbin inhibits EGFR ubiquitination and stabilizes it by interacting with c-CBL in colorectal cancer [89]. Overexpression of Erbin and ERBB2 in breast cancer patients with poor prognosis strengthened the hypothesis that Erbin facilitates tumor development, as is the case in MMTV-Neu mice [88]. Others studies related to breast cancer showed that, in vitro, depletion of Erbin in cancer cells leads to trastuzumab resistance and to invasion and metastasis via trastuzumab-induced AKT activation [90] and enhanced TRAIL sensitivity, which triggers tumorigenicity via the ERBB2/AKT/NF- $\kappa$ B pathway [91]. In the normal skin, subcellular localization of Erbin and ERBB2 varies during cell differentiation. In basal cell carcinoma (BCC), the most common form of skin cancer, Erbin and ERBB2 are redistributed from the plasma membrane to cytosolic aggregates, whereas in keratoacanthoma and squamous cell carcinoma, they remain normally distributed, suggesting a possible impact of this defective subcellular localization on BCC malignancy [92].

In cervical cancer cells, depletion of Erbin induces cell proliferation and migration, and STAT3-dependent resistance to anoikis [93] or induction of AKT-SKP2-p27 signaling [94]. Through its PDZ domain, Erbin can also modulate the Wnt/ $\beta$-catenin [47] and NF-кB [95] pathways. Erbin was also shown to inhibit cell proliferation and promote cell death of acute myeloid leukemia (AML) cells. However, increased miR-183-5p levels in certain AML patients negatively regulate Erbin expression and thus enhance RAF-MEK-ERK and PI3K/AKT/FoxO3 signaling [96].

Two studies have described the implication of Erbin in the two branches of TGF $\beta$ signaling (SMAD and PAKdependent) which plays a crucial role in embryonic development, adult life and diseases including cancer [59, 97]. Wilkes et al. found that, in epithelial cells, the serine/ threonine kinase PAK2 activity induced by TGF $\beta$ is repressed by Erbin leading to lower phosphorylation and more potent tumor-suppressive function of Merlin. In contrast, in fibroblasts where Erbin expression is much lower, Merlin phosphorylation by active PAK2 is high and induces increased cell proliferation [97]. Erbin also contributes to the negative regulation of TGF $\beta$ /ActivinA signaling in SMAD2/3-dependent transcription. Indeed, Erbin interacts with and sequesters phosphorylated SMAD2/3 in the cytoplasm, inhibits its association with SMAD4, and thus abolishes SMAD2/3 dependent transcription upon TGF $\beta$ activation. SARA competes with SMAD2/3 for the interaction with Erbin via its SSID (SARA and SMAD interacting domain), allows SMAD2/3 phosphorylation upon TGF $\beta$ /ActivinA stimulation, facilitates its nuclear transfer, and hence modulates the inhibitory effect of Erbin on transcription [57-59]. In a totally different context, Erbin was found to modulate TGF $\beta$ signaling. Indeed, it has been shown that, in T lymphocytes, STAT3 negatively regulates TGF $\beta$ signal via Erbin by formation of a STAT3-ErbinSMAD2/3 complex in the cytoplasm. Deregulation of this pathway in Erbin or STAT3 mutated patients leads to increased $\mathrm{T}$ helper type 2 cytokine expression and $\mathrm{IgE}$ production [98]. A somatic mutation of Erbin was also found in a patient with metastatic cholangiocarcinoma, leading to a $\mathrm{CD}^{+} \mathrm{T}$ cell-directed immune response and remarkable cancer regression by adoptive transfer [99]. Here, Erbin behaves as a bona fide tumor-associated antigen with therapeutic potential.

As previously mentioned for Scribble [82, 85], Erbin is also a potent regulator of the RAF-MEK-ERK pathway essential in tyrosine kinase signaling. As a known partner of Erbin and Scribble LRR domains, the scaffold LRR protein SHOC2/SUR8 clusters RAS and RAF, and functions as a regulatory protein for the PP1 phosphatase [36, 37]. In the complex, Scribble and Erbin function as switches to downregulate ERK activation and downstream events. Indeed, the SHOC2-PP1 holoenzyme interacts with M-RAS and therefore stimulates RAF activity through dephosphorylation of its inhibitory serine 259 and induction of ERK activation. The presence of Scribble in the protein complex prevents RAF activation by competing with SHOC2 and M-RAS for binding to PP1 [36].

Erbin also negatively modulates the RAF1-MEK-ERK pathway [100] by preventing SHOC2 interaction with RAS and RAF in a different manner than Scribble [37]. The interaction between Erbin and DSG1 also suppresses EGFR/ERK signaling in head and neck squamous cell carcinoma [101]. In colorectal cancer, Erbin suppresses RAS/RAF signaling by interacting with KSR1 (Kinase suppressor of Ras1) and negatively regulates EMT and tumorigenesis [68]. 


\section{Lano}

Less data is available regarding the contribution of Lano to cancer development. The first report of a role of Lano in cancer described its upregulation in hepatocellular carcinoma (HCC) patient samples. By multiple approaches, the authors provided evidence that its overexpression promotes tumorigenesis. In addition, the gene is located on chromosome $6 \mathrm{p} 12.1$, a region frequently amplified in HCC [102].

In an attempt to define the molecular mechanisms that drive HCC, LANO was later found to be one of twelve genes shown to be overexpressed and hypomethylated in patient samples. Its expression is negatively associated with overall survival of HCC patients [103]. Moreover, overexpression of LANO is associated with its mislocalization from the plasma membrane to the cytoplasm, as already described for Scribble. In the case of Scribble, this mislocalization correlates with activation of AKT/ATF2 pathway and loss of membranous E-cadherin [104]. Like Scribble, Lano was considered by the authors as a potential prognostic marker in HCC.

Recently, our lab discovered that low Lano expression is associated with a stem cell signature in the human mammary epithelial hierarchy and with cancer stem cell signatures in breast cancer samples. In vitro and in vivo studies suggest that Lano regulates breast cancer stem cell fate through the WNT/ $\beta$-catenin signaling, likely by modulation of ligand secretion. Here, in contrast to HCC, Lano thus behaves as a potential tumor suppressor [80].

Overall, these studies highlight the role of LAP proteins in many signaling pathways with some overlapping contributions, especially in the Wnt and ERK pathways (Fig. 4). The $L A P$ genes belong to a class of genes that exhibit both oncogenic and tumor suppressive functions (Table 2) and thus behave similarly to cancer genes such as $W T 1, P T P 1 B$, NOTCH, FAS, TP53, SYK or cell polarity genes (PAR6, $C D H 1, F A T 1)$ which are in general not disease-specific. Such is the case for LAP genes. However, in the case of $\mathrm{NOTCH}$, the cellular context is important as it acts as an oncogene in T-lineage acute lymphoblastic leukemia and as a tumor suppressor in solid tumors [105]. Proto-oncogenes with tumor suppressor function (POTSF) tend to be hub genes in protein-protein interaction networks with more than 100 interacting partners on average, whereas oncogenes and tumor suppressors have much less binding partners [106]. With more than 100 interactors each as mentioned above, $L A P$ genes can be classified as hub genes. We can infer that their over- or downregulation, or delocalization in tumors may similarly destabilize the composition, localization and regulation of LAP-associated signaling and architectural networks important in physiology, promoting cancer development.

\section{Redundancy between the LAP family members}

Despite their conserved modular organization, their overlapping expression/localization pattern in cells and tissues and some intra-family biochemical interactions, genetic studies in the mouse have demonstrated no obvious functional commonalities between LAP family members (see above). Moreover, only a few common interactors have been described so far, including those for the PDZ domains. In Drosophila, loss of scribble alone leads to mislocalization of apical proteins and adherens junctions to the basolateral membrane [2]. The situation is more complicated in mammalian cells as Scribble, Erbin and Lano are coexpressed and colocalized at the basolateral membrane. Deletion of either LAP has no profound effect on the epithelial organization. Recently, Choi et al. simultaneously silenced Scribble, Erbin, and Lano in polarized epithelial cells and showed that this combinatorial deletion disorganizes cell junctions and the cytoskeleton, and leads to mislocalization of apical and basolateral determinants. Interestingly, these defects can be rescued by reexpressing the LAP N-terminal region which is required for basolateral targeting [5, 17-19, 25]. Using a series of rescuing transgenes, Zeitler et al. also found that the N-terminal region of Drosophila Scribble is mandatory for cell polarity, cell proliferation control, and other Scribble functions [17]. We can infer from accumulated results that this conserved region encompassing the LRRs and LAPSDs contains important information for LAP functions. Mutations in Drosophila scribble causes loss of cell polarity and hyperproliferation of larval wing imaginal discs and brain lobes, resulting in the formation of neoplastic tumors and metastasis in cooperation with activated the Ras and Notch oncogenes $[14,15]$. This tumor-suppressing effect is not as strong in scribble-deficient mice, probably due to redundancy between the LAP family members, especially through their N-terminal region which exerts antiproliferative activities at the plasma membrane. We suspect that overexpression of Scribble (or Erbin and Lano) in tumors may cause a dramatic effect because of competitive displacement of other members of the family away from their physiological location leading to aberrant regulation of polarity and proliferation (Fig. 5).

\section{Concluding remarks}

The LAP family can be considered as an archetypal cell polarity protein family whose members have specific subcellular localizations, and scaffolding/signaling functions in many different polarized cell types. Functional redundancy between the four LAP members remains an issue that needs 


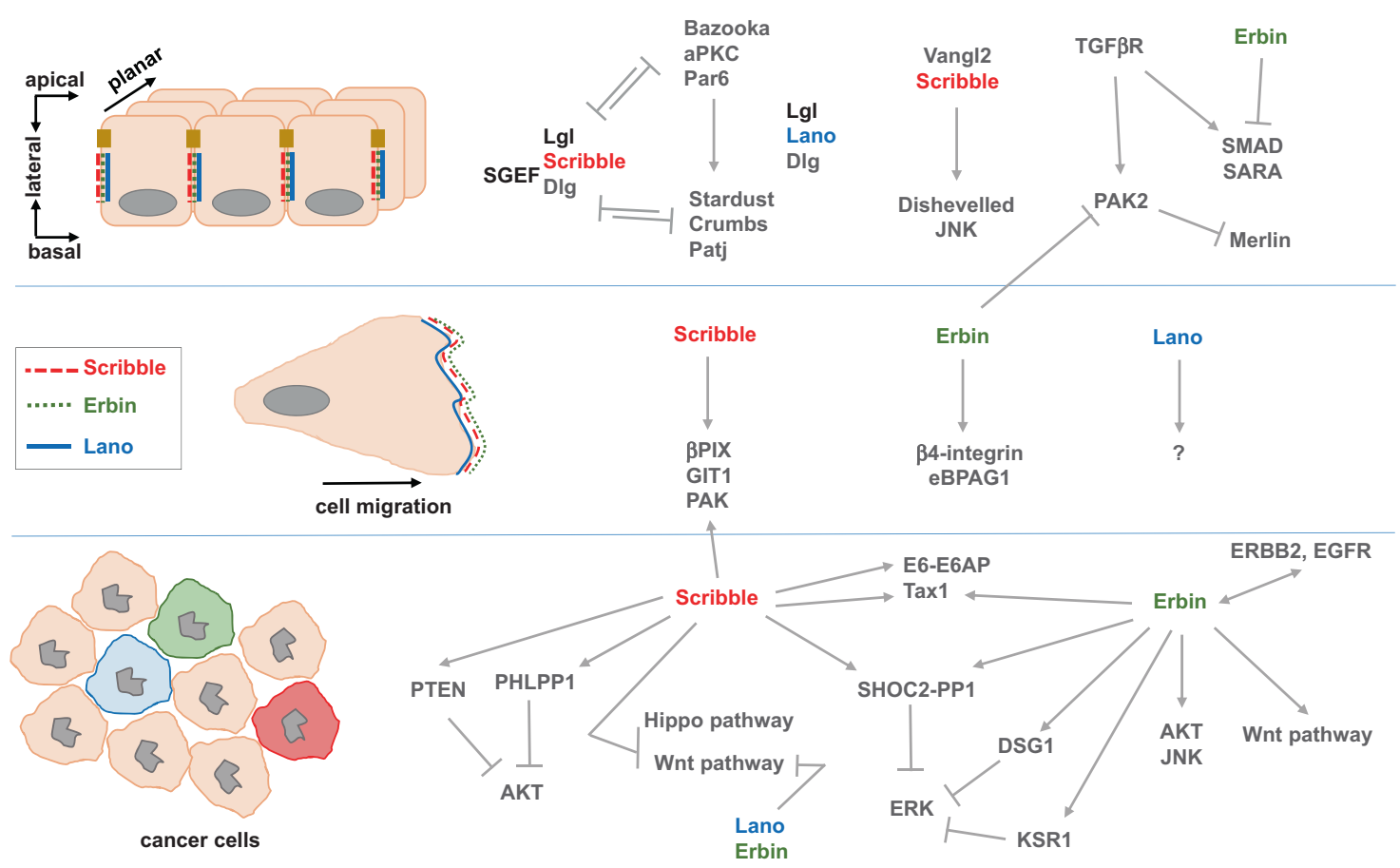

Fig. 4 Signaling pathways associated to LAP proteins in normal and cancer cells. The upper panel represents normal polarized epithelial cells, the middle panel migratory epithelial/fibroblastic cells and the lower panel cancer cells. Localization of LAP proteins is pinpointed in each situation. In cancer cells, LAP protein expression can be lost or increased, usually with associated mislocalization.

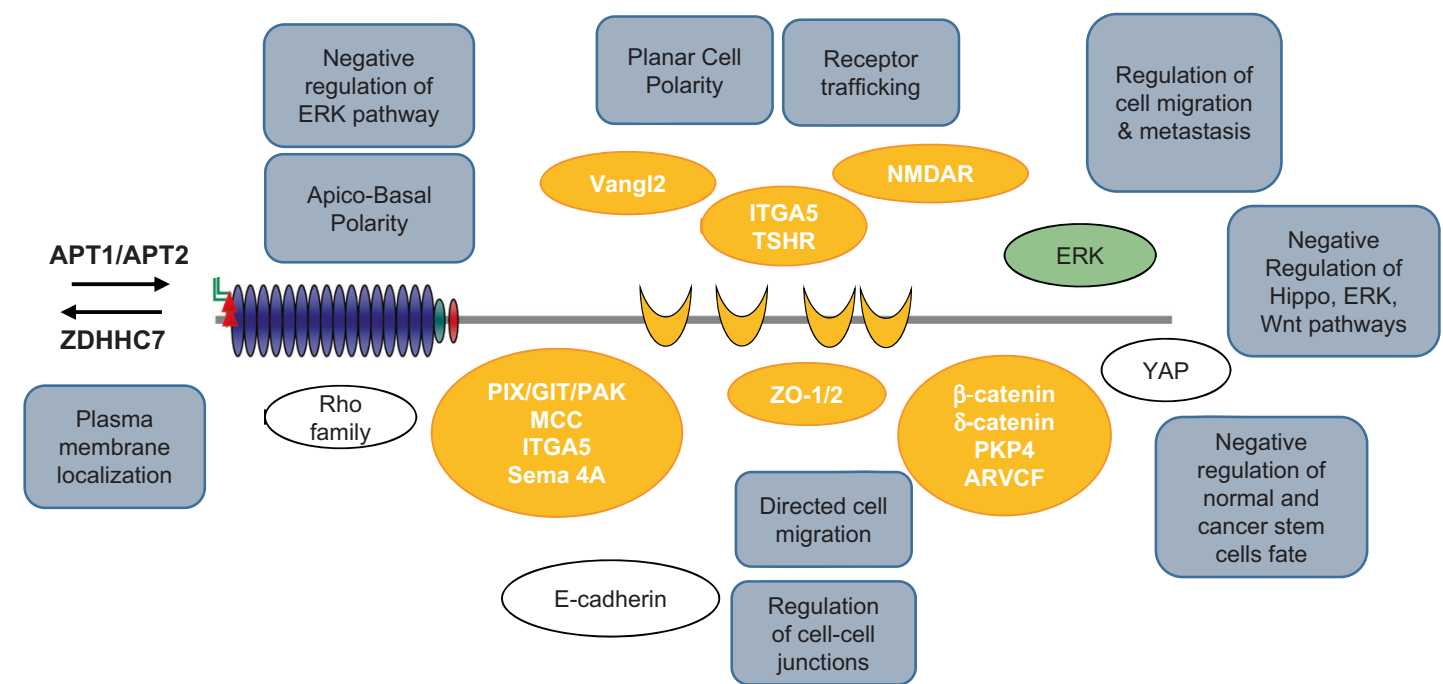

Fig. 5 Multiple partners and functions are associated with Scribble. Direct Scribble interactors are in orange (PDZ interactors) and green (ERK interacts with the Scribble C-terminal region) bullets.
Indirect and/or functional Scribble interactors are in white bullets. The Scribble-associated functions are in gray boxes.

to hematological tumors. However, their precise contribution to the different steps of tumorigenesis (cancer cell stemness, EMT,...) remains to be further investigated, especially considering the complexity of their associated protein networks and their numerous post-translational modifications of unknown significance (Fig. 3). Regarding stemness, Scribble and Lano have been involved in the
The role of Scribble, Erbin and, more recently Lano, in cancer is now well established in many contexts, from solid 
biology of stem cells in muscles [75] and in solid and hematological malignancies [80, 86, 110].

The initial assumption that these proteins would behave as tumor suppressors as is the case for Drosophila Scribble activity is now taken with caution. There is now growing evidence that overexpression of cell polarity proteins also occurs in cancer and that this correlates with poor prognosis and therapeutic resistance. The cell polarity PAR6 protein is for instance overexpressed in precancerous breast lesions and advanced primary human breast cancers [111], and planar cell polarity proteins are upregulated in many cancers [112]. In the case of Scribble, and to some extent of Lano, overexpression is often associated with mislocalization of the protein and, most probably, of its partners, thus affecting the regulation of downstream pathways. Another possibility could be that downregulation of ZDHHC7, a protein involved in S-palmitoylation of LAP proteins, may lead to their mislocalization and to disruption of their function [20]. Chemical compounds able to restore palmitoylation may have some potential therapeutic value, by relocating the proteins at cell-cell junctions. Interestingly, acyl protein thioesterase (APT1, APT2) inhibitors are able to repress Scribble depalmitoylation, favoring Scribble membrane localization and decreased cell growth [23]. This is apparently a mammalian specific feature which would be worthwhile exploiting in the future [21, 24]. Drugs affecting palmitoylation-depalmitoylation could thus constitute new cancer treatments by restoring the balance between tumor suppressor and oncogene properties of molecules such as the mammalian LAP proteins. Lastly, considering the binding partners of Erbin, especially of its PDZ domain, it is possible that inhibiting Erbin interactions could contribute to counteracting cancer progression, in particular in the case of the ERBB2 interaction [88]. However, given the promiscuity of PDZ domains, achieving specific inhibition remains a major challenge.

Acknowledgements We thank Philippe Roche and the Phyre2 web portal for the generation of images, and Valérie Depraetere for careful reading of the manuscript. J-PB's lab is funded by La Ligue Nationale Contre le Cancer (Label Ligue Equipe labellisée 2019), Fondation de France (fellowship to RK), the European PDZnet consortium (EU Horizon 2020 RIA under the Marie Skłodowska-Curie grant agreement no. 675341), and by Excellence Initiative of Aix-Marseille University-A*Midex, "Investissement d'avenir" (CapoStromEx). J-PB is a scholar of Institut Universitaire de France.

\section{Compliance with ethical standards}

Conflict of interest The authors declare that they have no conflict of interest.

Publisher's note Springer Nature remains neutral with regard to jurisdictional claims in published maps and institutional affiliations.

\section{References}

1. Printen JA, Sprague GF Jr. Protein-protein interactions in the yeast pheromone response pathway: Ste5p interacts with all members of the MAP kinase cascade. Genetics. 1994;138:609-19.

2. Bilder D, Perrimon N. Localization of apical epithelial determinants by the basolateral PDZ protein Scribble. Nature. 2000;403:676-80.

3. Dow LE, Brumby AM, Muratore R, Coombe ML, Sedelies KA, Trapani JA, et al. hScrib is a functional homologue of the Drosophila tumour suppressor Scribble. Oncogene. 2003;22:9225-30.

4. Nakagawa S, Huibregtse JM. Human scribble (Vartul) is targeted for ubiquitin-mediated degradation by the high-risk papillomavirus E6 proteins and the E6AP ubiquitin-protein ligase. Mol Cell Biol. 2000;20:8244-53.

5. Navarro C, Nola S, Audebert S, Santoni MJ, Arsanto JP, Ginestier C, et al. Junctional recruitment of mammalian Scribble relies on E-cadherin engagement. Oncogene. 2005;24:4330-9.

6. Borg JP, Marchetto S, Le Bivic A, Ollendorff V, Jaulin-Bastard F, Saito H, et al. ERBIN: a basolateral PDZ protein that interacts with the mammalian ERBB2/HER2 receptor. Nat Cell Biol. 2000;2:407-14.

7. Legouis R, Gansmuller A, Sookhareea S, Bosher JM, Baillie DL, Labouesse M. LET-413 is a basolateral protein required for the assembly of adherens junctions in Caenorhabditis elegans. Nat Cell Biol. 2000;2:415-22.

8. Apperson ML, Moon IS, Kennedy MB. Characterization of densin-180, a new brain-specific synaptic protein of the Osialoglycoprotein family. J Neurosci. 1996;16:6839-52.

9. Bilder D, Birnbaum D, Borg JP, Bryant P, Huigbretse J, Jansen E, et al. Collective nomenclature for LAP proteins. Nat Cell Biol. 2000;2:E114.

10. Santoni MJ, Pontarotti P, Birnbaum D, Borg JP. The LAP family: a phylogenetic point of view. Trends Genet. 2002;18:494-7.

11. Rubin I, Yarden Y. The basic biology of HER2. Ann Oncol. 2001;12:S3-8.

12. Huang YZ, Wang Q, Xiong WC, Mei L. Erbin is a protein concentrated at postsynaptic membranes that interacts with PSD95. J Biol Chem. 2001;276:19318-26.

13. Saito H, Santoni MJ, Arsanto JP, Jaulin-Bastard F, Le Bivic A, Marchetto S, et al. Lano, a novel LAP protein directly connected to MAGUK proteins in epithelial cells. J Biol Chem. 2001;276:32051-5.

14. Bonello TT, Peifer M. Scribble: a master scaffold in polarity, adhesion, synaptogenesis, and proliferation. J Cell Biol. 2019;218:742-56.

15. Stephens R, Lim K, Portela M, Kvansakul M, Humbert PO, Richardson HE. The Scribble cell polarity module in the regulation of cell signaling in tissue development and tumorigenesis. J Mol Biol. 2018;430:3585-612.

16. Kobe B, Deisenhofer J. The leucine-rich repeat: a versatile binding motif. Trends Biochem Sci. 1994;19:415-21.

17. Zeitler J, Hsu CP, Dionne H, Bilder D. Domains controlling cell polarity and proliferation in the Drosophila tumor suppressor Scribble. J Cell Biol. 2004;167:1137-46.

18. Dow LE, Kauffman JS, Caddy J, Zarbalis K, Peterson AS, Jane $\mathrm{SM}$, et al. The tumour-suppressor Scribble dictates cell polarity during directed epithelial migration: regulation of Rho GTPase recruitment to the leading edge. Oncogene. 2007;26:2272-82.

19. Legouis R, Jaulin-Bastard F, Schott S, Navarro C, Borg JP, Labouesse M. Basolateral targeting by leucine-rich repeat domains in epithelial cells. EMBO Rep. 2003;4:1096-102.

20. Chen B, Zheng B, DeRan M, Jarugumilli GK, Fu J, Brooks YS, et al. ZDHHC7-mediated S-palmitoylation of Scribble regulates cell polarity. Nat Chem Biol. 2016;12:686-93. 
21. Izawa I, Nishizawa M, Hayashi Y, Inagaki M. Palmitoylation of ERBIN is required for its plasma membrane localization. Genes Cells. 2008;13:691-701.

22. Strassburger K, Kang E, Teleman AA. Drosophila ZDHHC8 palmitoylates scribble and Ras64B and controls growth and viability. PLoS ONE. 2019;14:e0198149.

23. Hernandez JL, Davda D, Cheung See Kit M, Majmudar JD, Won SJ, Gang M, et al. APT2 inhibition restores Scribble localization and S-palmitoylation in snail-transformed cells. Cell Chem Biol. 2017;24:87-97.

24. Khoury MJ, Bilder D. Distinct activities of Scrib module proteins organize epithelial polarity. Proc Natl Acad Sci USA. 2020;117:11531-40.

25. Choi J, Troyanovsky RB, Indra I, Mitchell BJ, Troyanovsky SM. Scribble, Erbin, and Lano redundantly regulate epithelial polarity and apical adhesion complex. J Cell Biol. 2019;218:2277-93.

26. Nourry C, Grant SG, Borg JP. PDZ domain proteins: plug and play! Sci STKE. 2003; 2003: RE7.

27. Liu X, Fuentes EJ. Emerging themes in PDZ domain signaling: structure, function, and inhibition. Int Rev Cell Mol Biol. 2019;343:129-218.

28. Ivarsson Y, Arnold R, McLaughlin M, Nim S, Joshi R, Ray D, et al. Large-scale interaction profiling of PDZ domains through proteomic peptide-phage display using human and viral phage peptidomes. Proc Natl Acad Sci USA. 2014;111:2542-7.

29. Lim KYB, Godde NJ, Humbert PO, Kvansakul M. Structural basis for the differential interaction of Scribble PDZ domains with the guanine nucleotide exchange factor beta-PIX. J Biol Chem. 2017;292:20425-36.

30. Birrane G, Chung J, Ladias JA. Novel mode of ligand recognition by the Erbin PDZ domain. J Biol Chem. 2003;278:1399-402.

31. Laura RP, Witt AS, Held HA, Gerstner R, Deshayes K, Koehler MF, et al. The Erbin PDZ domain binds with high affinity and specificity to the carboxyl termini of delta-catenin and ARVCF. J Biol Chem. 2002;277:12906-14.

32. Appleton BA, Zhang Y, Wu P, Yin JP, Hunziker W, Skelton NJ, et al. Comparative structural analysis of the Erbin PDZ domain and the first PDZ domain of ZO-1. Insights into determinants of PDZ domain specificity. J Biol Chem. 2006;281:22312-20.

33. Daulat AM, Wagner MS, Walton A, Baudelet E, Audebert S, Camoin L, et al. The tumor suppressor SCRIB is a negative modulator of the Wnt/beta-Catenin signaling pathway. Proteomics. 2019;19:21-2.

34. Li X, Yang H, Liu J, Schmidt MD, Gao T. Scribble-mediated membrane targeting of PHLPP1 is required for its negative regulation of Akt. EMBO Rep. 2011;12:818-24.

35. Kallay LM, McNickle A, Brennwald PJ, Hubbard AL, Braiterman LT. Scribble associates with two polarity proteins, Lgl2 and Vang12, via distinct molecular domains. J Cell Biochem. 2006;99:647-64.

36. Young LC, Hartig N, Munoz-Alegre M, Oses-Prieto JA, Durdu $\mathrm{S}$, Bender S, et al. An MRAS, SHOC2, and SCRIB complex coordinates ERK pathway activation with polarity and tumorigenic growth. Mol Cell. 2013;52:679-92.

37. Dai P, Xiong WC, Mei L. Erbin inhibits RAF activation by disrupting the sur-8-Ras-Raf complex. J Biol Chem. 2006;281:927-33.

38. McDonald C, Chen FF, Ollendorff V, Ogura Y, Marchetto S, Lecine $\mathrm{P}$, et al. A role for Erbin in the regulation of Nod2dependent NF-kappaB signaling. J Biol Chem. 2005;280:40301-9.

39. How JY, Caria S, Humbert PO, Kvansakul M. Crystal structure of the human Scribble PDZ1 domain bound to the PDZ-binding motif of APC. FEBS Lett. 2019;593:533-42.

40. Feigin ME, Akshinthala SD, Araki K, Rosenberg AZ, Muthuswamy LB, Martin B, et al. Mislocalization of the cell polarity protein scribble promotes mammary tumorigenesis and is associated with basal breast cancer. Cancer Res. 2014;74:3180-94.

41. Arnaud C, Sebbagh M, Nola S, Audebert S, Bidaut G, Hermant A, et al. MCC, a new interacting protein for Scrib, is required for cell migration in epithelial cells. FEBS Lett. 2009;583:2326-32.

42. Metais JY, Navarro C, Santoni MJ, Audebert S, Borg JP. hScrib interacts with $\mathrm{ZO}-2$ at the cell-cell junctions of epithelial cells. FEBS Lett. 2005;579:3725-30.

43. Audebert S, Navarro C, Nourry C, Chasserot-Golaz S, Lecine P, Bellaiche Y, et al. Mammalian Scribble forms a tight complex with the betaPIX exchange factor. Curr Biol. 2004;14:987-95.

44. Nola S, Sebbagh M, Marchetto S, Osmani N, Nourry C, Audebert $\mathrm{S}$, et al. Scrib regulates PAK activity during the cell migration process. Hum Mol Genet. 2008;17:3552-65.

45. Awadia S, Huq F, Arnold TR, Goicoechea SM, Sun YJ, Hou T, et al. SGEF forms a complex with Scribble and Dlg1 and regulates epithelial junctions and contractility. J Cell Biol. 2019;218:2699-725.

46. Jaulin-Bastard F, Arsanto JP, Le Bivic A, Navarro C, Vely F, Saito $\mathrm{H}$, et al. Interaction between Erbin and a Catenin-related protein in epithelial cells. J Biol Chem. 2002;277:2869-75.

47. Ress A, Moelling K. The PDZ protein erbin modulates betacatenin-dependent transcription. Eur Surg Res. 2008;41:284-9.

48. Harmon RM, Simpson CL, Johnson JL, Koetsier JL, Dubash AD, Najor NA, et al. Desmoglein-1/Erbin interaction suppresses ERK activation to support epidermal differentiation. J Clin Invest. 2013;123:1556-70.

49. Thomas M, Massimi P, Navarro C, Borg JP, Banks L. The hScrib/ Dlg apico-basal control complex is differentially targeted by HPV16 and HPV-18 E6 proteins. Oncogene. 2005;24:6222-30.

50. Thomas M, Myers MP, Massimi P, Guarnaccia C, Banks L. Analysis of Multiple HPV E6 PDZ Interactions Defines TypeSpecific PDZ Fingerprints That Predict Oncogenic Potential. PLoS Pathog. 2016;12:e1005766.

51. Kranjec C, Tomaic V, Massimi P, Nicolaides L, Doorbar J, Banks L. The high-risk HPV E6 target scribble (hScrib) is required for HPV E6 expression in cervical tumour-derived cell lines. Papillomavirus Res. 2016;2:70-7.

52. Liu H, Golebiewski L, Dow EC, Krug RM, Javier RT, Rice AP. The ESEV PDZ-binding motif of the avian influenza A virus NS1 protein protects infected cells from apoptosis by directly targeting Scribble. J Virol. 2010;84:11164-74.

53. Okajima M, Takahashi M, Higuchi M, Ohsawa T, Yoshida S, Yoshida $\mathrm{Y}$, et al. Human T-cell leukemia virus type 1 Tax induces an aberrant clustering of the tumor suppressor Scribble through the PDZ domain-binding motif dependent and independent interaction. Virus Genes. 2008;37:231-40.

54. Peres E, Blin J, Ricci EP, Artesi M, Hahaut V, Van den Broeke A, et al. PDZ domain-binding motif of Tax sustains T-cell proliferation in HTLV-1-infected humanized mice. PLoS Pathog. 2018;14:e1006933.

55. Favre B, Fontao L, Koster J, Shafaatian R, Jaunin F, Saurat JH, et al. The hemidesmosomal protein bullous pemphigoid antigen 1 and the integrin beta 4 subunit bind to ERBIN. Molecular cloning of multiple alternative splice variants of ERBIN and analysis of their tissue expression. J Biol Chem. 2001;276:32427-36.

56. Rangwala R, Banine F, Borg JP, Sherman LS. Erbin regulates mitogen-activated protein (MAP) kinase activation and MAP kinase-dependent interactions between Merlin and adherens junction protein complexes in Schwann cells. J Biol Chem. 2005;280:11790-7.

57. Warner DR, Pisano MM, Roberts EA, Greene RM. Identification of three novel Smad binding proteins involved in cell polarity. FEBS Lett. 2003;539:167-73.

58. Dai F, Chang C, Lin X, Dai P, Mei L, Feng XH. Erbin inhibits transforming growth factor beta signaling through a novel Smadinteracting domain. Mol Cell Biol. 2007;27:6183-94. 
59. Sflomos G, Kostaras E, Panopoulou E, Pappas N, Kyrkou A, Politou AS, et al. ERBIN is a new SARA-interacting protein: competition between SARA and SMAD2 and SMAD3 for binding to ERBIN. J Cell Sci. 2011;124:3209-22.

60. Liu H, Wang S, Hang W, Gao J, Zhang W, Cheng Z, et al. LET413/Erbin acts as a RAB-5 effector to promote RAB-10 activation during endocytic recycling. J Cell Biol. 2018;217:299-314.

61. Simeone L, Straubinger M, Khan MA, Nalleweg N, Cheusova T, Hashemolhosseini S. Identification of Erbin interlinking MuSK and ErbB2 and its impact on acetylcholine receptor aggregation at the neuromuscular junction. J Neurosci. 2010;30:6620-34.

62. Jaulin-Bastard F, Saito H, Le Bivic A, Ollendorff V, Marchetto $\mathrm{S}$, Birnbaum D, et al. The ERBB2/HER2 receptor differentially interacts with ERBIN and PICK1 PSD-95/DLG/ZO-1 domain proteins. J Biol Chem. 2001;276:15256-63.

63. Anastas JN, Biechele TL, Robitaille M, Muster J, Allison KH, Angers S, et al. A protein complex of SCRIB, NOS1AP and VANGL1 regulates cell polarity and migration, and is associated with breast cancer progression. Oncogene. 2012;31:3696-708.

64. Chastney M, Lawless C, Humphries J, Warwood S, Jones M, Knight D et al. Definition of the fibroblast adhesome using multiplexed proximity biotinylation. Preprint at https://www. biorxiv.org/content/10.1101/2020.01.24.918458v1.full. 2020.

65. Horton ER, Byron A, Askari JA, Ng DHJ, Millon-Fremillon A, Robertson J, et al. Definition of a consensus integrin adhesome and its dynamics during adhesion complex assembly and disassembly. Nat Cell Biol. 2015;17:1577-87.

66. Robertson J, Jacquemet G, Byron A, Jones MC, Warwood S, Selley JN, et al. Defining the phospho-adhesome through the phosphoproteomic analysis of integrin signalling. Nat Commun. 2015;6:6265.

67. Osmani N, Vitale N, Borg JP, Etienne-Manneville S. Scrib controls Cdc42 localization and activity to promote cell polarization during astrocyte migration. Curr Biol. 2006;16:2395-405.

68. Stevens PD, Wen YA, Xiong X, Zaytseva YY, Li AT, Wang C, et al. Erbin Suppresses KSR1-Mediated RAS/RAF Signaling and Tumorigenesis in Colorectal Cancer. Cancer Res. 2018;78:4839-52.

69. Yoshihara K, Ikenouchi J, Izumi Y, Akashi M, Tsukita S, Furuse M. Phosphorylation state regulates the localization of Scribble at adherens junctions and its association with E-cadherin-catenin complexes. Exp Cell Res. 2011;317:413-22.

70. Nagasaka K, Pim D, Massimi P, Thomas M, Tomaic V, Subbaiah VK, et al. The cell polarity regulator hScrib controls ERK activation through a KIM site-dependent interaction. Oncogene. 2010;29:5311-21.

71. Phua DC, Humbert PO, Hunziker W. Vimentin regulates scribble activity by protecting it from proteasomal degradation. Mol Biol Cell. 2009;20:2841-55.

72. Murdoch JN, Rachel RA, Shah S, Beermann F, Stanier P, Mason CA, et al. Circletail, a new mouse mutant with severe neural tube defects: chromosomal localization and interaction with the looptail mutation. Genomics. 2001;78:55-63.

73. Moreau MM, Piguel N, Papouin T, Koehl M, Durand CM, Rubio $\mathrm{ME}$, et al. The planar polarity protein Scribble1 is essential for neuronal plasticity and brain function. $J$ Neurosci. 2010;30:9738-52.

74. Jarjour AA, Boyd A, Dow LE, Holloway RK, Goebbels S, Humbert $\mathrm{PO}$, et al. The polarity protein Scribble regulates myelination and remyelination in the central nervous system. PLoS Biol. 2015;13:e1002107.

75. Ono Y, Urata Y, Goto S, Nakagawa S, Humbert PO, Li TS, et al. Muscle stem cell fate is controlled by the cell-polarity protein Scrib. Cell Rep. 2015;10:1135-48.

76. Baker L, BeGora M, Au Yeung F, Feigin ME, Rosenberg AZ, Lowe $\mathrm{SW}$, et al. Scribble is required for pregnancy-induced alveologenesis in the adult mammary gland. J Cell Sci. 2016;129:2307-15.
77. Tao Y, Dai P, Liu Y, Marchetto S, Xiong WC, Borg JP, et al. Erbin regulates NRG1 signaling and myelination. Proc Natl Acad Sci USA. 2009;106:9477-82.

78. Rachmin I, Tshori S, Smith Y, Oppenheim A, Marchetto S, Kay $\mathrm{G}$, et al. Erbin is a negative modulator of cardiac hypertrophy. Proc Natl Acad Sci USA. 2014;111:5902-7.

79. Chong CH, Li Q, Mak PHS, Ng CCP, Leung EHW, Tan VH, et al. Lrrc7 mutant mice model developmental emotional dysregulation that can be alleviated by mGluR5 allosteric modulation. Transl Psychiatry. 2019;9:244.

80. Lopez Almeida L, Sebbagh M, Bertucci F, Finetti P, Wicinski J, Marchetto S, et al. The SCRIB paralog LANO/LRRC1 regulates breast cancer stem cell fate through WNT/beta-Catenin signaling. Stem Cell Rep. 2018;11:1040-50.

81. Zhan L, Rosenberg A, Bergami KC, Yu M, Xuan Z, Jaffe AB, et al. Deregulation of scribble promotes mammary tumorigenesis and reveals a role for cell polarity in carcinoma. Cell. 2008;135:865-78.

82. Godde NJ, Sheridan JM, Smith LK, Pearson HB, Britt KL, Galea RC, et al. Scribble modulates the MAPK/Fra1 pathway to disrupt luminal and ductal integrity and suppress tumour formation in the mammary gland. PLoS Genet. 2014;10:e1004323.

83. Elsum IA, Martin C, Humbert PO. Scribble regulates an EMT polarity pathway through modulation of MAPK-ERK signaling to mediate junction formation. J Cell Sci. 2013;126:3990-9.

84. Ivanov AI, Young C, Den Beste K, Capaldo CT, Humbert PO, Brennwald $\mathrm{P}$, et al. Tumor suppressor scribble regulates assembly of tight junctions in the intestinal epithelium. Am J Pathol. 2010;176:134-45.

85. Pearson HB, Perez-Mancera PA, Dow LE, Ryan A, Tennstedt P, Bogani D, et al. SCRIB expression is deregulated in human prostate cancer, and its deficiency in mice promotes prostate neoplasia. J Clin Invest. 2011;121:4257-67.

86. Cordenonsi M, Zanconato F, Azzolin L, Forcato M, Rosato A, Frasson C, et al. The Hippo transducer TAZ confers cancer stem cell-related traits on breast cancer cells. Cell. 2011;147:759-72.

87. Hawkins ED, Oliaro J, Ramsbottom KM, Newbold A, Humbert PO, Johnstone RW, et al. Scribble acts as an oncogene in Emumyc-driven lymphoma. Oncogene. 2016;35:1193-7.

88. Tao Y, Shen C, Luo S, Traore W, Marchetto S, Santoni MJ, et al. Role of Erbin in ErbB2-dependent breast tumor growth. Proc Natl Acad Sci USA. 2014;111:E4429-4438.

89. Yao S, Zheng P, Wu H, Song LM, Ying XF, Xing C, et al. Erbin interacts with $\mathrm{c}-\mathrm{Cbl}$ and promotes tumourigenesis and tumour growth in colorectal cancer by preventing c-Cbl-mediated ubiquitination and down-regulation of EGFR. J Pathol. 2015;236:65-77.

90. Liu D, Shi M, Duan C, Chen H, Hu Y, Yang Z, et al. Downregulation of Erbin in Her2-overexpressing breast cancer cells promotes cell migration and induces trastuzumab resistance. Mol Immunol. 2013;56:104-12.

91. Liu N, Zhang J, Liu S, Liu Y, Zheng D. Erbin-regulated sensitivity of MCF-7 breast cancer cells to TRAIL via ErbB2/AKT/ NF-kappaB pathway. J Biochem. 2008;143:793-801.

92. Lebeau S, Masouye I, Berti M, Augsburger E, Saurat JH, Borradori $\mathrm{L}$, et al. Comparative analysis of the expression of ERBIN and Erb-B2 in normal human skin and cutaneous carcinomas. $\mathrm{Br}$ J Dermatol. 2005;152:1248-55.

93. Hu Y, Chen H, Duan C, Liu D, Qian L, Yang Z, et al. Deficiency of Erbin induces resistance of cervical cancer cells to anoikis in a STAT3-dependent manner. Oncogenesis. 2013;2:e52.

94. Huang H, Song Y, Wu Y, Guo N, Ma Y, Qian L. Erbin loss promotes cancer cell proliferation through feedback activation of Akt-Skp2-p27 signaling. Biochem Biophys Res Commun. 2015;463:370-6.

95. Hrdlickova R, Nehyba J, Roy A, Humphries EH, Bose HR Jr. The relocalization of $\mathrm{v}$-Rel from the nucleus to the cytoplasm 
coincides with induction of expression of Ikba and nfkb1 and stabilization of I kappa B-alpha. J Virol. 1995;69:403-13.

96. Zheng Z, Zheng X, Zhu Y, Gu X, Gu W, Xie X, et al. miR-183$5 \mathrm{p}$ inhibits occurrence and progression of acute myeloid leukemia via targeting Erbin. Mol Ther. 2019;27:542-58.

97. Wilkes MC, Repellin CE, Hong M, Bracamonte M, Penheiter SG, Borg JP, et al. Erbin and the NF2 tumor suppressor Merlin cooperatively regulate cell-type-specific activation of PAK2 by TGF-beta. Dev Cell. 2009;16:433-44.

98. Lyons JJ, Liu Y, Ma CA, Yu X, O’Connell MP, Lawrence MG, et al. ERBIN deficiency links STAT3 and TGF-beta pathway defects with atopy in humans. J Exp Med. 2017;214:669-80.

99. Tran E, Turcotte S, Gros A, Robbins PF, Lu YC, Dudley ME, et al. Cancer immunotherapy based on mutation-specific CD4+ T cells in a patient with epithelial cancer. Science. 2014;344:641-5.

100. Huang YZ, Zang M, Xiong WC, Luo Z, Mei L. Erbin suppresses the MAP kinase pathway. J Biol Chem. 2003;278:1108-14.

101. Valenzuela-Iglesias A, Burks HE, Arnette CR, Yalamanchili A, Nekrasova O, Godsel LM, et al. Desmoglein 1 regulates invadopodia by suppressing EGFR/Erk signaling in an Erbindependent manner. Mol Cancer Res. 2019;17:1195-206.

102. Li Y, Zhou B, Dai J, Liu R, Han ZG. Aberrant upregulation of LRRC1 contributes to human hepatocellular carcinoma. Mol Biol Rep. 2013;40:4543-51.

103. Hua S, Ji Z, Quan Y, Zhan M, Wang H, Li W, et al. Identification of hub genes in hepatocellular carcinoma using integrated bioinformatic analysis. Aging. 2020;12:5439-68.

104. Wan S, Meyer AS, Weiler SME, Rupp C, Toth M, Sticht C, et al. Cytoplasmic localization of the cell polarity factor scribble supports liver tumor formation and tumor cell invasiveness. Hepatology. 2018;67:1842-56.

105. Aster JC, Pear WS, Blacklow SC. The varied roles of notch in cancer. Annu Rev Pathol. 2017;12:245-75.

106. Shen L, Shi Q, Wang W. Double agents: genes with both oncogenic and tumor-suppressor functions. Oncogenesis. 2018;7:25.

107. Yuan J, Aikawa S, Deng W, Bartos A, Walz G, Grahammer F, et al. Primary decidual zone formation requires Scribble for pregnancy success in mice. Nat Commun. 2019;10:5425.

108. Ludford-Menting MJ, Oliaro J, Sacirbegovic F, Cheah ET, Pedersen N, Thomas SJ, et al. A network of PDZ-containing proteins regulates $\mathrm{T}$ cell polarity and morphology during migration and immunological synapse formation. Immunity. 2005;22:737-48.

109. Schurmann C, Dienst FL, Palfi K, Vasconez AE, Oo JA, Wang $\mathrm{S}$, et al. The polarity protein Scrib limits atherosclerosis development in mice. Cardiovasc Res. 2019;115:1963-74.

110. Althoff M, Nayak R, Hegde S, Wellendorf A, Bohan B, Filippi $\mathrm{MD}$ et al. Yap1-Scribble polarization is required for hematopoietic stem cell division and fate. Blood. https://doi.org/10. 1182/blood.2019004113.

111. Nolan ME, Aranda V, Lee S, Lakshmi B, Basu S, Allred DC, et al. The polarity protein Par6 induces cell proliferation and is overexpressed in breast cancer. Cancer Res. 2008;68:8201-9.

112. Daulat AM, Borg JP. Wnt/planar cell polarity signaling: new opportunities for cancer treatment. Trends Cancer. 2017;3:113-25.
113. Takizawa S, Nagasaka K, Nakagawa S, Yano T, Nakagawa K, Yasugi $\mathrm{T}$. et al. Human scribble, a novel tumor suppressor identified as atarget of high-risk HPV E6 for ubiquitin-mediated degradation, interacts with adenomatous polyposis coli. Genes Cells. 2006;11:453-64.

114. Montcouquiol M, Sans N, Huss D, Kach J, Dickman JD, Forge A. et al. Asymmetric localization of Vangl2 and Fz3 indicate novel mechanisms forplanar cell polarity in mammals. J Neurosci. 2006;26:5265-75.

115. Sundell GN, Arnold R, Ali M, Naksukpaiboon P, Orts J, Guntert $\mathrm{P}$. et al. Proteome-wide analysis of phospho-regulated PDZ domain interactions. Mol Syst Biol. 2018;14:e8129.

116. Nakagawa S, Yano T, Nakagawa K, Takizawa S, Suzuki Y, Yasugi T. et al. Analysis of the expression and localisation of a LAP protein, humanscribble, in the normal and neoplastic epithelium of uterine cervix. Br J Cancer. 2004;90:194-9.

117. Skouloudaki K, Puetz M, Simons M, Courbard JR, Boehlke C, Hartleben B. et al. Scribble participates in Hippo signaling and is required fornormal zebrafish pronephros development. Proc Natl Acad Sci USA. 2009;106:8579-84.

118. Zheng W, Umitsu M, Jagan I, Tran CW, Ishiyama N, BeGora M. et al. An interaction between Scribble and the NADPH oxidase complex controls M1 macrophage polarization and function. Nat Cell Biol. 2016;18:1244-52.

119. Boisguerin P, Leben R, Ay B, Radziwill G, Moelling K, Dong L. et al. An improved method for the synthesis of cellulose membrane-boundpeptides with free $\mathrm{C}$ termini is useful for PDZ domain binding studies. Chem Biol. 2004;11:449-59.

120. Ress A, Moelling K. Interaction partners of the PDZ domain of erbin. Protein Pept Lett. 2006;13:877-81.

121. Izawa I, Nishizawa $\mathrm{M}$, Tomono $\mathrm{Y}$, Ohtakara $\mathrm{K}$, Takahashi $\mathrm{T}$, Inagaki M. ERBIN associates with p0071, an armadillo protein, at cell-cell junctions of epithelial cells. Genes Cells. 2002;7:475-85.

122. Song C, Wang W, Li M, Liu Y, Zheng D. Tax 1 enhances cancer cellproliferation via Ras-Raf-MEK-ERK signaling pathway. IUBMB Life. 2009;61:685-92.

123. Li H, Zhou W, Li L, Wu J, Liu X, Zhao L. et al. Inhibition of neddylation modification sensitizes pancreatic cancer cells to gemcitabine. Neoplasia. 2017;19:509-18.

124. Wu H, Yao S, Zhang S, Wang JR, Guo PD, Li XM. et al. Elevatedexpression of Erbin destabilizes ERalpha protein and promotes tumorigenesis in hepatocellular carcinoma. J Hepatol. 2017;66:1193-204.

125. Elsum IA, Yates LL, Pearson HB, Phesse TJ, Long F, O'Donoghue R. et al. Scrib heterozygosity predisposes to lung cancer and cooperates withKRas hyperactivation to accelerate lung cancer progression in vivo. Oncogene. 2014;33:5523-33.

126. Pearson HB, McGlinn E, Phesse TJ, Schluter H, Srikumar A, Godde NJ. et al. The polarity protein Scrib mediates epidermal development andexerts a tumor suppressive function during skin carcinogenesis. Mol Cancer. 2015;14:169.

127. Kelley LA, Mezulis S, Yates CM, Wass MN, Sternberg MJ. The Phyre2 web portal for protein modeling, prediction and analysis. Nat Protoc. 2015;10:845-58. 